\title{
SUPPRESSED, DELAYED, DAMAGING AND AVOIDED DIVORCES
}

\author{
RosweLL H. JoHNSON*
}

\section{INTRODUCTION}

The first purpose of a good divorce process is to make a wise decision-i.e., to decide for a divorce if such a course promotes the welfare of those concerned, or to deny it if the divorce would work more harm for those concerned than benefit. But there is a further need-viz., that the process should accomplish its purpose with a minimum of harm. It is true that at one time the opposite was sought-viz., to make the process so harmful to the plaintiff and the others that the court would receive few applications. There is now so much evidence, however, that a divorce in some cases prevents much damage that the former attitude is diminishing. This article in this symposium limits itself to the one inquiry-how can we make divorce as harmless as possible without decreasing the soundness of the decisions.

Most of the articles in this symposium will be written from the viewpoint of the judge, attorney, teacher of law, or sociologist. However, the picture may be made more adequate if the divorce process is also scrutinized by a psychologist in marriage counseling, who is in a position to see the real causes more clearly than the mere statement of the grounds reveals. It is well to examine the workings of the minds of those who later become divorce litigants.

The phrase Suppressed Divorce will be taken to mean a potential divorce which would be more beneficial than harmful, taking all probable results into consideration, but which does not take place. A model divorce law should seek to provide a basis, procedure, and practice which will minimize such suppression while avoiding divorces which are more harmful than beneficial. This latter is an important but not a sole task. A law should not have as its sole aim the reduction of the divorce rate. It should seek the wisest decision in each case as such, and let the divorce rate be so determined.

The discussion of Delayed Divorce will deal with those cases in which an earlier divorce was impending but delayed, and it would have been better if the divorce had occurred earlier for one reason or another. The various proposals for imposed delay to accomplish some supposed advantage will be examined and evaluated. Consideration will also be given to other causes of delay.

Suppressed and delayed divorces are not the only means of unnecessarily dam-

* B.S., University of Chicago; M.S., University of Wisconsin; Ph.D., University of Pittsburgh. Member, American Psychological Association. Author (with Paul B. Popenoe) of Applied Evgenics (1933); (with H. R. Randolph and E. E. Pixley) of Looking Toward Marriage (I943). Dircctor of Counscling, American Institute of Family Relations, Hollywood, California. 
aging the spouses; there are still other sources of damage arising in the divorce process when trial is planned for and proceeds. These are treated in Part III as Damaging Divorces.

The Avoided Divorces which will be discussed are those that were contemplated or sought but never obtained because some factor came into play which so far repaired the individuals or the situation that a divorce was no longer felt desirable. A distinction will be made between a mere willingness to resume the marriage state with nothing changed and a genuine alteration of the causative factors.

\section{Suppressed Divorces}

We turn first to the many causes that suppress divorce, with which the marriage counselor becomes familiar. The divorce attorney will hear many of these, but the purpose of this article is to present a wide range of categories that impress the marriage counselor in order that few will be missed in considering a new divorce law. The order of the categories presented here has not received enough controlled research to be other than the opinion of the author, but the categories themselves seem valid. This is especially true as it greatly varies from country to country, state to state, religion to religion, class to class, and-the often neglected factorclique to clique. With some categories two or three are almost equal as to order of importance in the writer's mind.

I. Poverty. A low personal income intensifies greatly other categories to be considered later, such as damage to social or professional status and an inadequate state law. Where there is a high personal income, some of the considerations to follow later have much less effect. Where one can easily cut bonds and live for a protracted period in a foreign country or distant state, setting up a substantial domicile there, many of the factors to follow are much less effective. To a considerable extent, divorce like membership in a profession of very expensive and protracted training is an economic class privilege. There is a common saying that "Desertion is the poor man's divorce." The husband or wife may fear that the alimony, payments from community property, support money for children, and his own support cannot be met on his income.

While society is very widely willing to provide a public defender to the criminal who is in poverty, the poverty stricken wife whose sadistic husband is seriously and persistently damaging her and her children is sometimes denied real help by the state, since she must have money to start the proceedings and may not have it. Cases are known where the husband has pared down the household allowance of an income-less wife below a subsistence standard to prevent her from getting cash for court costs and has then taunted her with her impotence. Our cold indifference to the damage that may and often does result to the spouse and children of a psychopathic spouse who sadistically beats the children results largely from ignorance. The woman who files a criminal complaint in such a case does not have 
to advance court costs, but if she asks for a remedy much more effective and persisting, she is deterred by being forced to advance the court costs. The practice of demanding court costs in advance in divorce suits before the court knows the circumstances works badly.

The difficulty reaches much further than court costs. Such a wife may know that the family is already on the ragged edge of subsistence and that the attorney fees to be procured from the husband cannot be paid without the danger of his being taken into custody which almost certainly forces him into nonpayment for the support of the children. Great Britain, long so backward in socially minded divorce laws, is in this respect now ahead. Some attorneys have rarely or never seen such a case, because of a class-limited practice, but the district social worker, the probation and parole workers, and the clergyman do see them in substantial numbers.

A common response to the difficulty mentioned above is to point to the resources of a legal aid society. In spite of the great value of this help it is inadequate to meet this large need for the following reasons:

a. Rarely does the aid include all the court costs.

b. The aid as to legal services consists often in a referral to an outside attorney at lower cost and, in part, deferred payment, which the family either thinks it cannot meet or cannot in fact meet.

c. Some legal aid societies demand that the family involved be demonstrably impecunious on the records of some social agency and referred by it to the legal aid society. Some of the needy cases have not been in such an agency because of a sense of pride (whether the poverty is sudden and recent or of long standing). Some legal aid societies do act on their own initiative in a few cases, but this is not generally known.

d. Effective, strong legal aid societies are rarely found in small communities.

e. Even where we have a legal aid society whose service is free from the above difficulties there is a widespread ignorance of its very existence. One legal aid society does not dare advertise its existence because it is already swamped with work.

To help meet this need the county should provide an office of Public Attorney involving no fees. This office with this new name should include family law litigation as well as criminal. Where there is a law school in the county, the office of Public Attorney may well offer apprenticeship to suitably advanced students as is now often true in the legal aid society. Such an office should refer an applicant for help in the matter of divorce or annulment or arrears to the staff serving the courts of jurisdiction in this field (this may well be in a different building from the courthouse but close to it). The staff may recommend to the Public Attorney that the case is suitable for its services, with a statement that the economic circumstances justify its taking the case. However, if the appropriations for the staff are inadequate, the staff should give first claim to the cases referred to it by the judge, the remaining cases getting cursory investigation and an early report as to the appropriateness of reference to the Public Attorney.

2. Loss in Social Prestige. This may operate directly to the point of involving 
ostracism in some cultures or circles, even damaging a person's occupational status. In some occupations such as the ministry, teaching, medicine, and politics, the mere fact of "divorce" without any investigation may be a barrier to a position or lead to discharge or slowed promotion. The harmful attitude of wholesale condemnation often persists regardless of the obvious fact that some divorced people are superior as spouses to the average mate. The very irrationality of the condemning attitude is a factor which makes this category so important. It assumes a lumping together of divorces and calls them all bad-ignoring the fact that in some cases one partner has been bad "spouse material" from the beginning or is now. Furthermore, blame cannot be placed on faulty mate-selection in all cases. The change may come after marriage, frequently from some physiological alteration or some exceptional stress.

A person who is a divorcee is not necessarily at fault. Indeed a mother having young children where both the children and she are being seriously damaged by the marriage is acting unethically in continuing the damage as she does, if she declines to obtain a divorce if it is available. The following two cases are cited to emphasize the fact that suppression of divorce for the sake of the children is often harmful. The first is that of a psychopathic father who could not be brought to treatment and was seriously worsening the condition of a psycopathic son. The need for the parents' separation was urgent and it was desired by the mother, but poverty blocked action for divorce. Another case was one in which both the mother and the counselor recognized the danger of incestuous rape on the daughter but fear of her husband prevented the mother from taking any step toward divorce.

The drift in public opinion to the realization that the fact that a person is divorced is not necesarily a fault was greatly helped by Lichtenberger (professor of sociology at the University of Pennsylvania at the time) in his important book, Divorce: A Sociological Interpretation. ${ }^{1}$ This was already a trend of the times, springing from the increasing objectivity, which was a product of better and more extensive education of the public. There is, however, still a lag in public opinion in this matter.

3. Religious Inhibitions. Since a beneficial divorce does just what the spirit of Christianity purports to do-to increase benefits and reduce harms-it is inconsistent to find some religious groups, who would seek to stop such actions in all cases. Yet this is done on a basis of the letter rather than the spirit. Some churches prohibit all divorce, some recognize only divorces granted because of adultery, still others accept adultery and desertion by a non-believer, and finally some recognize a divorce granted on the basis of "adultery or a moral equivalent." This step to extend the grounds of divorce to add to adultery "or its moral equivalent" is a movement toward carrying out the Christian purpose of increasing benefits and reducing harms. However, it still places the whole issue on a past specific offense and is therefore a long way from a consideration of the real question of, "How

\footnotetext{
1 (1930).
} 
beneficial will the marriage be from this time on?" It also surprisingly ignores the distinction between forgiven and unforgiven, which is such an important concept held by those who use this formula. The placing of divorce decisions on a basis of their results in welfare strengthens the ethical position of the church.

The philosophy of the juvenile court became widely spread and its spirit invaded the criminal court, producing probation, parole, and the revisable and beneficial term of sentence. One would have thought that attention in the matter of divorce would be transferred similarly from the penalization of a single past offense for which there was a specific fixed penalty to the investigation into the quality of the marriage and its contributing factors. Apparently, however, that will take a longer time in the church, where one might expect more of such idealism, than in the courts.

There remains the further religious inhibition of refusing remarriage to the divorced in general. Let us consider the case where a husband was divorced in his twenties because his wife developed a promiscuous and extreme sexual activity, probably because of organic origin. He had a daughter of three. Divorce took place on the urging of his sisters to prevent damage to the young daughter. One of the sisters took the daughter for a while, although she had four children and was living on a limited income. The man remarried by thirty and provided a good home for the daughter and himself, leading to a life long devotion. He subsequently became the father of three children who have led lives of distinction. What good purpose could have been accomplished by forcing this man of unusual cordiality and love into an unwelcome celibacy and near loss of his daughter?

The most hopeful aspect of these hard and unsympathetic religious inhibitions is the gradual march in humaneness at the annual church conferences, notably in the last few years. An especially hopeful sign is the realization that unhappy marriage situations are highly varied and complicated so that decisions formerly hard and fast for a whole class are now left to investigation as to the particular situation. However this is too often left to a very busy bishop. To make it as useful as it might be, the clergyman involved needs a specialist to work out the details and make a recommendation.

4. "For the Sake of the Children." This category as a cause of suppressed divorce is probably the one most frequently mentioned by those partners in an unhappy marriage where parenthood is involved. It is without doubt a real consideration by many parents who have a genuine interest in their children. It is also very much associated with the second category-"Loss of Prestige"-for the general public thinks that divorce regularly works more harm than good to the children. There is a common impression abroad that the great contributor of delinquency in children is the neglect of the children in the "broken marriage." The statistical category "broken homes" includes many sorts. Yet the term is transformed in some people's minds to the children of the divorced only. We should remember that the home which was later broken by divorce was nearly always for a time, usually 
a long time, an unhappy home and bad environment for the child. The child guidance clinics which work with children of many sorts have a very large load of children from damaging but not broken homes. The proper procedure is to examine without prejudice in each maladjusted home whether the termination of the home as it is, will in the future produce a better or worse environment for the child.

It is well to list the various kinds of damage that children suffer in bad homes, since there is a tendency to idealize unrealistically parents, as shown in the contention that sex education is better done by the parent than by others, with no recognition of exceptions. Some ways in which the child is damaged seriously in the particular home by the action of either or both parents are:

a. Being rejected.

b. Witnessing the strained relations and lack of courtesy, respect, and love between parents.

c. Being beaten severely.

d. Persistently fearing a possible beating.

e. Persistently being insulted.

f. Improper sexual advances to or practices with the child or children.

g. Being taught criminal behavior.

h. Being taught to disesteem unfairly the other parent.

i. Being taught gravely unhygienic practices.

j. Being exposed to witnessing brutal or inconsiderate sexual activities of the parents.

k. Being exposed to abuse, sexual or violent, by brother and sister, with the parents' indifference.

5. Insanity. The failure to provide insanity as a ground for divorce and unreasonable definitions of insanity, where this is a ground, is another cause for suppressed divorce. It is quite understandable that the early laws which gave recognition to the importance of including insanity as a ground for divorce should be drawn with over-severe limitations. However, now that such grounds are used in many states it is high time that these limitations be examined as to their merit. The faults present are:

a. The law commonly stipulates that the insanity be sworn to be incurable by two psychiatrists. In this day of rapidly developing medical care it is unreasonable to expect a psychiatrist to assert that a condition is incurable, although the chance of complete permanent cure may be almost impossible in a particular case. However, he might conscientiously assert that the outlook is unfavorable to a sufficient improvement to justify continuing the marriage. We do not demand that the case of an habitual drunkard be incurable before relief is given. Why should we do so in the case of insanity where the damage is likely to be greater?

b. The individual must have been institutionalized for three years or more in one state. This is to be added to the time, often long, before the institutionalization started while the patient was unfitted as a spouse. It is excessive.

c. The institutionalization is sometimes not in a state institution, yet the statutes generally stipulate the period spent must be in a state institution. It is customary for the well-to-do to place their members in private institutions. Are they any the less 
insane? While undoubtedly additional safeguards would be advisable for those outside the state institutions, certification by state psychiatrists or by those on a list of psychiatrists specially licensed for this duty would suffice.

Some of the worst cases of unsuccessful marriages are those of individuals who are undergoing a worsening of their psychological condition from a poor personality to a pre-psychotic stage and thence to psychosis. The public should realize that insanity does not ordinarily arrive at a particular moment, but is a slow development, although some extra stress speeds the change. In these cases should the plaintiff file early enough the divorce ensues, but should there be delay until the individual is declared insane the action is held up in some states until the insane spouse has been for three years in a state institution and the psychiatrists will swear to incurable insanity. There is an inconsistency here because after the declaration of insanity the spouse is less fit and there is more reason for divorce.

6. Cruelty. The omission of the ground of cruelty from the District of Columbia law shows us how illusory it is to suppose that the transferral of divorce legislation to the jurisdiction of the United States Congress by constitutional amendment would bring any improvement in divorce law. No ground of divorce could possibly be more urgent and compelling than cruelty where it is so persistent and extreme as to be torture. The "wrongful infliction of grievous physical or mental suffering" would seem to be a reasonable definition. To demand language more stringent than this could fail to protect some needy spouses.

7. Drunkenness. The definition of habitual drunkenness has gone so far in its intensification as to make this reasonable ground seldom available. Thus in California we have a definition that implies that the damage to the marriage is less important than the maintenance of a job. A reasonable definition would seem to be an addiction to alcoholic drinks or harmful drugs to a degree that has made the marriage seriously harmful to the spouse and that has continued steadily or at intervals for more than a month.

8. Separation. The use of a desertion ground with denial of a separation ground makes the failing marriage worse if it is undesired by only one party than where both reject it. This absurd situation has received very little attention compared to the equivalent situation in the defense of recrimination which has been so severely and justly condemned. The reasoning is the same and a separation ground (one year is an ample term) is needed. This also has the value of preventing prolonged exploitative separate-maintenance and limited divorce abuses.

9. Fraud. The definition of fraud in annulment cases has in the practice of some courts been narrowed to that which goes to the essence of marriage, viz., sex and reproduction. But let us consider the fraudulent representation of one's ability to be gainfully employed, to be free from a seriously disabling disease, or to be free from any condition that would warrant a divorce. Many authors have properly shown great concern over mate selection as a preventer of unwise marriages, yet the law here tolerates a fraud more important than an infertility at some 
ages. Fraudulent representation as to traits which, if known, might well have prevented the marriage should be included with the "essence of the marriage" grounds. We might better say "goes to the essence of mate selection, sex, and reproduction."

Io. Fears of Retaliation or Embarrassment. There is occasionally a fear (sometimes well justified) that the spouse will retaliate in some severe manner-blows, insults, slander, hostility, animosity, disinheritance, or change of beneficiary. Worse than all that is the fear that the spouse might purposely damage the children for retaliation, or damage a real or wrongly suspected paramour. These are real cases. Many a woman has been threatened with violent harm should she file a divorce or even consult the American Institute of Family Relations as in one of my cases. Another client said, "He must not know I am here because I am afraid of what he might do." It is probable that the abandonment of the adversary principle of divorce would help in their situation, but it cannot be wholly prevented.

A wife may refuse to seek a divorce because of the fear of drawing upon herself a cross-complaint that would allege, exaggerate, or falsely affirm very damaging material, sometimes with the intention of bringing it to the attention of an employer or possible future employer. This may be an unsubstantiated fear, or a real hazard as where the other spouse, who has previously struck the wife, may have promised to damage the fearful spouse if the divorce complaint is filed.

A wife also often fears the unknown, that divorce might subject her to an exaggerated degree of public ignominy, or unknown damages, or economic misfortunes, fears which may greatly exceed the actual probabilities. Many litigants, especially those who are shy and nervous (and all the more so, if likely to receive publicity), are also acutely disturbed by the embarrassment of giving testimony involving sexual and other intimate situations. Sometimes rather than undergo the ordeal (it is often exaggerated in their apprehension) they will tolerate a damaging marriage. The remedy is the closed door and sealed record on demand of either litigant. This device is actually the law in one state.

Ir. Inadequacy of the Home-State Laws. The notable case is that of New York with the ground of adultery only. Those who resort to out-of-state divorce are put to heavy expense that many cannot afford. When we consider the case of South Carolina, which jumped from no grounds to four grounds in one act, the outlook is not hopeless. We may confidently expect more adequate grounds within the next few sessions of the state legislature. It is inhumane when we have such states as New York to seek utterly to suppress the out-of-state divorce by nullifying the "full faith and credit" clause by various subterfuges.

I2. Recrimination. This absurd foisting on divorce actions of a rule developed for different purposes and wholly ill-adapted to divorce, calls only for mention as it has been amply covered by others in this symposium. The clear-cut abolition by one state has worked well.

13. Condonation. The condonation defense is most harmful to constructive 
efforts to improve the condition of the marriage and will be discussed under Avoided Divorces. It deserves mention here also as a tricky method of defeating a divorce action. A ground for action can be too readily nullified by this simple expedient wilefully practiced on an ignorant spouse, who finds himself or herself duped. It works in another way, moreover, by increasing the expense of divorce, because it is for condonation reasons that the rule that the plaintiff must leave the house or apartment is used. The condonation defense tends to force people apart instead of promoting reconstruction of the marriage. It should be wholly abandoned.

I4. Collusion. The well-intentioned divorce litigant and attorney wish to accomplish the divorce with the least possible damage to anyone. To this end only one divorce ground is filed and that the one available (frequently several are available) which will do the least damage. The evidence chosen is to be the least damaging and embittering possible and yet be adequate. The attorney watches the judge's nod of sufficiency in order to offer as little evidence as required. That selected should avoid, so far as may be, items of special offense to the defendant. Special effort is made not to allege adultery, drunkenness, drug addiction, conviction of felony, or insanity, if these may be avoided for the reasons given. A conference might well be held by the litigants as to the choice of existing evidence to accomplish this purpose. Yet it is probable that some judges would hold the above course to be collusive or conniving and refuse the divorce.

All four of the defenses, recrimination, condonation, collusion, and connivance, should be abolished for another important reason in addition to that of harmfulness. They are provided in order to try to force the spouses to act as actual adversaries. If we abolish adversary action, then the decision can be based on the significant data only without these subsidiary and interfering issues, which sometimes force a wrong decision. As an analogy let us consider a case where a competent student unfairly helps another student in an examination. The appropriate punishment is not to declare that the helper failed the examination (which is absurd) but to provide a punishment that does not involve a wrong decision as to the examination, or better yet, provide more efficient proctoring of the examination to prevent such offenses. What needs to be done to abolish the four defenses is to abolish the adversary principle.

15. The Need for a Corroborating Witness. A few cases are suppressed because the only corroborating witness would be a son or a daughter whom the plaintiff is unwilling to have put on the stand. In other cases, especially where cruelty is cunningly concealed (pinching of large areas or bending of joints leave no marks) or where the insulting epithets and threats are uttered in private, corroboration is not available. Let us compare the case where direct evidence is usually impossible, i.e., actual observed adultery, when the court dispenses with it and substitutes inference from other circumstances. So we may well contend that where evidence points to concealment of cruelty, the court should be allowed to forego corroboration on this point. 
16. Opposition from Third Persons. There are cases where the children and other heirs of the father or mother attempt to suppress a divorce because they fear that a divorce might lead to remarriage and they know that it will or might lead to the new spouse's getting a substantial share of an estate, which they wish to divide among themselves. This is a deplorable situation which is probably not capable of direct correction. Education or counseling eventually may help reduce cases.

There is often pressure from other relatives against the possible divorce, or from employers or business associates, because they think the divorce would work against their interest, or from other members of some group which thinks the divorce would work against the interest of the group, such as a church or club. The will to divorce sometimes takes time to grow adequate to resist this influence.

I7. The Outlook for Gainful Employment by the Wife after the Divorce. Some wives already have a good position or could readily resume a past position. On the other hand, many who married while young, with little education, are divorced while devoid of a pleasing personality or a skill for which there is demand. If a divorce be contemplated by such a one after $5^{0}$ there is often a grave reluctance to undergo the anxieties of getting a job with a low income and some disagreeable features, resulting from its low skill. We assume there is little or no income to be expected from the ex-husband. Such a woman not infrequently abandons her wish for a divorce and tolerates a "grin and bear it" marriage until still later, when it sometimes becomes too intolerable to endure longer.

r8. Contrariness. There may exist an aroused hostile reaction against the other spouse who wishes the divorce. From this aroused hostility there sometimes comes a desire to thwart the other in everything desired.

19. Refusal to face facts. The feeling of obligation to see it through "better or worse" may head off an evaluation of which is the better course. This may have the neurotic quality of a compulsion, be more in the nature of habit, or be accentuated by guilt feelings, especially where there is illness, physical or mental. Frequently there is an unwillingness to break long, thoroughly established habits, because of a liking for the habitual life, or there may be a pessimistic feeling that life is a "vale of tears" anyway and nothing better can be found by any action. Moreover, no matter how grave the prognosis really is, some spouses are strongly biased toward a favorable one, and keep hanging on with constantly thwarted hopes. This is especially true where the offending spouse is an alcoholic of long standing or a paranoid personality.

20. Ignorance. In some cases the ignorance of the law is so great that the spouse thinks he or she has no grounds, when in fact the state law provides them.

2r. Judicial Hostility, Ignorance, or Bias. Until lately the courts have failed to note that society has a real interest in reducing the number of marriages that work actual social damage, as well as in conserving marriage as a whole. A typical court statement reads:" As the law favors marriage, and disfavors divorce, the court will

${ }^{2}$ Rinehart v. Rinehart, 9r N. Y. Eq. 354,357 , rro Atl. 29, 30 (1920). 
do nothing to facilitate the latter, but will only dissolve the marriage relation when the complaining party is strictly entitled to a decree." It is a great advance from such an avowal of bias to a statement by Judge Paul W. Alexander, "In the divorce court the criterion would be: What is best for the family." Some judges, too, have an avowed bias which would be lessened by a wider knowledge of this complex field. The common practice of distributing divorce cases among nearly all the judges in the courts having jurisdiction sacrifices the advantage of specialization, so that the client gets less expert service.

\section{II}

\section{Divorce Delays}

Divorce Delays are usually imposed by law, legal procedure, or court practice. Still others arise outside these areas as a consequence of indecision or the operation for a time of some of the factors mentioned under Suppressed Divorces.

\section{A. Incidental Delays. These include:}

x. Waiting for the attorney to prepare and present the complaint.

2. Waiting for the court to set the date for a preliminary hearing.

3. Waiting to get the interlocutory hearing set.

4. If contested, a much longer delay for the trial and while trial proceeds.

B. Laws or proposed laws to impose specific additional delay with no specific effort toward reconstruction to be made during the period. These include:

r. A compulsory delay between preliminary hearing or filing of application and the trial.

2. A compulsory delay withholding the divorce decision, after trial, for one year.

3. Voiding a remarriage before the expiration of a certain delaying period after divorce.

4. No legal provision, but a policy of giving other issues precedence over divorce litigation in the setting of dates in order to produce delay.

5. Granting an interlocutory decree stating a final divorce may be had if either litigant requests it after a period of one year (this is the period in four states; it is a shorter period in some others).

The interlocutory method (No. 5) above is the most common method for delay and has worked so badly in California that almost every session a bill is introduced to shorten it. It deserves a fuller consideration than the other methods of enforced delay. Among the arguments against it are:

a. The principal purpose of the interlocutory decree seems to have been the expectation of promoting spontaneous reconciliation. In California, a condition has been imposed that tends to make the interlocutory a preventer of reconciliation. This comes about because the court demands before the final decree an affidavit from the plaintiff or defendant that there has been no cohabitation since the interlocutory decree. This is done on the excuse of the defense of condonation, a feature that we have seen is harmful in other ways.

b. As a consequence, attorneys commonly advise those in the interlocutory period to have nothing to do with each other. If one spouse urges a trial reconciliation, the 
other spouse sometimes suspects that it is a trick to prevent obtaining the affidavit in order to defeat the divorce.

c. After divorce, the welfare of the divorced individuals is furthered by an early normalization of their lives, frequently through remarriage. The one year delay keeps them more or less maladjusted in that period and delays the readjustment process. Depression is not uncommon during this period and sometimes is partly alleviated by the clearing effect of the final decree.

d. The welfare of the children is sometimes enhanced by the establishmnt of a new home, but such improvement of the home environment is often postponed by this long period while one spouse must live apart from the children.

e. The chance of remarriage of a divorced woman drops rapidly with the years and is much lower from thirty on. The year's delay reduces that chance.

f. Adultery is very materially increased because the spouse who has an interlocutory decree sometimes becomes ready to remarry and is held back only by this period of the interlocutory. The frustration being, they believe, unnecessary and unwise, they have little respect for it and hence sometimes anticipate the planned marriage by sexual relations or else have conflicts over the solicitation to such adultery.

g. The public is sometimes confused about the two decrees, so that bigamy results, which might well have been avoided. Judge Willis of the Superior Court in Los Angeles County, has called attention to how frequent this is the case.

h. The spouse is often naturally looking around for a new mate during the interlocutory period, since he or she is for most practical purposes already divorced, so that a twilight zone between marriage and non-marriage is created which makes it more difficult for the mores to restrict courtship activities to the unmarried.

i. The alleged advantages of the interlocutory decree are illusory. Lasting reconciliations that turn out successfully are seldom accomplished by this device.

j. If a state sought to make positive efforts toward constructive reconciliation during the interlocutory, some advantages would accrue, but in fact in California only one county makes any such attempt and that is limited to the families with children by means of the Children's Court of Conciliation. Such efforts are made both before and after the interlocutory decree on request.

Dr. Clair E. Gore of North Hollywood, California, has made the valuable suggestion that if the one year interlocutory must be kept, then the one year should start with the beginning of any period of desertion or separation, or at the time of filing the divorce petition.

\section{Delays for the specific purpose of investigation and attempts at reconstruction} of the marriage. These include:

I. Adjustable to the time needed-but with a maximum of two months within which report must be made, as here recommended.

2. The report to be held back for six months before action by the judge.

The proposal of such a long time as a required uniform six months' delay for investigation and counseling in all uncontested or all divorce cases has the following serious objections:

a. In fact the court assistant will in nearly all cases reach a real termination of the counseling much earlier. This is shown in the Michigan Friend of the Court act, where a long fixed period was originally provided and found to be an obstacle and was changed to a flexible provision. It is also shown in the experience of the non-court 
marriage counseling services in Boston, Los Angeles, and Philadelphia and in my own private practice where a termination one way or the other is reached in nearly all cases well in advance of this period.

b. The six month provision would work not in the interest of good investigation and counseling, but as one more rigidity of which we have seen the evil results in the provision of the 6 to I2 months' delay after the interlocutory decree.

c. There is a strong chance of further deterioration in morale during the substantially unused period between the end of the significant counseling period and the end of the six months.

d. The idea of very long counseling processes is largely the attempt to apply methods which are prohibitively expensive for a court staff even though they seemed desirable elsewhere.

e. There are dangers of violence, extreme hostility, living in conditions of frequent quarreling, a worsening psychopathic condition, or a damaging environment to the children; any of these make it important to free the individual from this condition as soon as the report is ready.

f. The expense with the six month period is increased because mark-time clients will still have to call for some ill-spared attention. The item of expense is likely to be the second most serious obstacle in promoting the new divorce procedure. It must be kept down in every feasible way, without too much loss of efficiency.

g. The morale of the counselor is damaged when a large proportion of his cases are "frozen cases." They reduce the attention he can give to "live cases."

h. This heavy load of frozen cases calls for a larger staff, but it is evident that the courts will have difficulty in being able to get enough efficient staff members and would be forced to dip down into the ill-prepared for appointments.

i. Suppose an excellent reconstruction of the marriage has been accomplished by the counselor and spouses, how much better to have the report and the case cleared rather than have it drag along as a court case.

j. After the new bill has been put in operation its spread to other states will depend on how well it works and how expensive it is. It is imperative that these features of feasibility be given serious consideration.

For these reasons the period before report to the judge should be flexible with a two months' maximum.

D. Cases where trial is suspended waiting for a response from the litigants. This is in the proposed plan of some members of the Interprofessional Commission.

A proposal that there be a ban-period of three weeks' delay after the judge announces a tentative decision in order to give opportunity for the litigants to ask for an open trial if that is preferred to the acceptance of the decree by both parties (this has probably been offered to make the proposed law more legally defensible and as such is not here opposed; however, if a delay is introduced here, it weakens the case for imposing the various other delays at earlier stages).

The proposal of Paul G. James of Des Moines, Iowa, that the final decree be given first as a divorce decree only, and that thereafter immediately the allied issues of custody and property be decreed in a separate decision, would seem desirable, especially in a non-adversary system. Many more decisions would be accepted then as to the real issue, than would be where issues of custody of children and property settlements are handled in one divorce decree, where unfair pressure is to be feared. 


\section{Damaging Divorces}

In Part III damages arising during the period when the spouses are preparing for and obtaining the divorce will be analyzed. Almost every factor in suppressing or delaying a divorce could be listed here also as the process of deciding upon or avoiding a divorce is usually a gradual one and in the transition one of the suppressing or delaying factors may have operated in a damaging way. In addition, harm is needlessly produced in our divorce law in practice in still other ways.

$r$. There is the practice of direct and cross examination of the plaintiff and his corroborative witnesses in open court. This is supposed to produce greater veracity. A comparison of such testimony with that given to a competent investigator in private impresses me as yielding less truth than the investigator gets, because the open court situation in itself has important error-producing effects. There is no question but what it is a damaging experience to the litigant directly, especially through later dissemination of the testimony, often garbled in form, by press or gossip. It is not only the actual experience but also the apprehension that it might be worse, that damages. The practice of some states in permitting closed doors and sealed records is more humane and worthy of emulation by other states.

2. To demand a corroborating witness for substantiation of the grounds is in some cases needlessly damaging to plaintiff and such witnesses. The problem of the corroborating witness was found to be a difficulty in discussing suppressed divorces. It is introduced again because it harms even when the divorce action does proceed. Those asked to be corroborating witnesses often refuse because (a) they fear personal violence, (b) they fear some more subtle retaliation, (c) they fear their testimony will be garbled if reported or retold, (d) they dislike to be associated with court action in any way, or (e) they fear they may be thought to have some improper connection with the litigant they help. If they acquiesce, the same fears harass them and often produce undesirable tensions. If the court is so eager not to have perjury practiced against it, should it not be eager to be protected from such deception by this easy means of concealment? The remedy is easy: not to demand corroboration when there is reason to suspect purposive concealment from sight and sound of severe cruelty.

3. The list of explicit grounds as is the almost universal practice in writing divorce laws can be understood historically because of the adversary principle. However, as a matter of actually evaluating a marriage, the rigidity and arbitrariness of listed grounds is absurd. It is a truism that the real grounds are often different from those alleged. Furthermore they should be, so long as we use the present lists of "grounds." Thus it is best for the spouse to use only one criterion -a choice from available grounds of that which will probably produce the most benefit and least harm to all affected by the decision.

4. There has been a tendency lately to seek to restrict more and more the resource of serving by publication when the defendant cannot be found for personal 
service. There is a proper solicitude that the defendant be notified, but should we not be equally solicitous to see that a defendant shall not be able to deny the plaintiff a hearing by hiding or running away?

5. If feasible neither spouse should choose an attorney likely to be personally offensive to the other.

6. Once a divorce is determined upon after a fair trial of ways to alter the causes, each litigant should seek to avoid delays so far as may be, as they are likely to increase bitterness and damage.

7. A suit for limited divorce or "separate maintenance," not aimed at a break in the marriage, but improperly to exploit the other spouse, should be frowned upon as unethical. It is exacting a contribution for which there is no exchange.

8. The defendant should not be present at a default hearing.

9. Nearly all cases should be uncontested, for to hold an unwilling and, especially, a hostile spouse "on a leash" is harmful in many ways.

Io. Settlement of custody and money should be arranged so far as may be between the spouses, leaving the deadlocks for the attorneys plus considerations of legal concern. If, however, the ability to arrange these matters in good spirit is not present, the attorneys should relieve them of the strain.

Ix. A haunting feeling of guilt or remorse is harmful. The litigant should look forward to the new life as constructively as possible, including a new marriage except where there is some serious handicap such as psychopathic personality, very poor health, or very poor life expectancy.

I2. The notion that propriety demands a complete avoidance or ostracism of the ex-spouse is not well grounded. The spouses should let bygones be bygones and treat each other with the same courtesy as friends, when they happen to meet, or meet because of reasonable visitation to children.

I3. The hostility of some divorcing couples becomes so great that they seek to make the divorce as damaging as they can to the other spouse. The divorce law should be such as to restrain such vicious behavior. The formal written complaint should contain grounds only, without specific allegations, or even better, under the proposed Interprofessional Commission law, not even that. The closed door and sealed record on demand of either litigant would help.

I4. The vindictive spouse may ask for separate maintenance or a limited divorce (which does not permit remarriage in a few states) in order to block a beneficial remarriage. The legislation in reference to these two actions calls for revision to make them available in a much more restricted range.

I5. There is at present a use of threats to use damaging testimony or to hold out for unreasonable custody or financial adjustment, which may go to actual blackmail in some cases. The James' plan of a divided decision is aimed to reduce this damage. It deserves attention, so great is the need.

16. There may be involvement of the other spouse in needless expense. A woman plaintiff may fail to use caution and discretion in trying to see that the lawyer's fee to be paid by the husband is not exorbitant or beyond his means. 
I7. There is difficulty in the fixing of alimony to make it a tolerable financial load for the husband to carry and yet fair to the wife and children. The wife sometimes holds out for such unfair alimony payments, considering his income and her condition, that the load would be crushing. This may act to suppress the divorce. But sometimes it is so important to him that he get the divorce that he tolerates payments so great that it would effectually prevent remarriage or continuance of his education or training. It should also be remembered that the widening span of years between the upper age at which a divorced woman can enter the labor market and her life expectancy often tends to throw the woman on relief or drain her children's resources too far or call for alimony too high to permit the husband to remarry. All are undesirable choices. The law should consider it normal and socially desirable for the widowed and divorced to remarry unless there are substantial grounds to the contrary and should have concern that excessive alimony charges should not stand in the way in so far as feasible.

18. The practice of having the husband necessarily leave the home on filing a divorce complaint is harmful because sometimes his remaining there is beneficial to each of them and to the children. Moreover the chance of resumption of the marriage is sometimes better, as it gives an opportunity to work on a plan of action looking toward reconstruction. The theory of having him leave is based on the fear that his remaining will be construed to condone the grounds alleged. But since the condonation might lead to the plaintiff's wishing to dismiss the complaint it is more useful than not. This is further evidence for abandoning the defense of condonation entirely.

\section{IV}

\section{The Avoided Divorce}

Divorce intentions are sometimes discontinued because of some pressure such as described in the Suppressed Divorce section. Then one of the litigants goes back to the state of marriage in depression rather than joy and with no confidence in a lasting resumption. In general a reconciliation that lasts for only a short time leaves the situation with less prospect of eventual success than if it had not taken place. In fact it is desirable that we make a distinction between a mere reconciliation, where there is only a cessation of the divorce effort, and a reconstruction of the marriage where the causative factors of the failure are effectively changed. The former is usually not of value; the latter is our goal. We shall consider as avoided divorces not such abortive reconciliations but an abandonment of the divorce intent or effort where there is a good reconstruction accomplished.

The success of introducing into the divorce process what has been so well called by Dr. Wendy Stewart (I946) and Judge Alexander a therapeutic purpose will depend largely upon whether such an effort will remain at the old propaganda level or proceed on a sounder basis. Are such results possible? They are most common when there is no difficulty in the personality of the spouses, and the trouble arises 
from a situation not of their own making, or one ignorantly gotten into, or where they were the helpless victims of the situation. Here help may lie in environmental manipulation, when this is possible. Some of the best and easiest improvements are accomplished in such cases. One of the commonest of such cases is a troublemaking "in-law" personality. Difficulties also may arise from sheer privation, which may lessen as the family salary increases, if the couple stick together that long. At the other extreme is the series of psychopathological conditions-the insane, the severely neurotic, the psychopathic personality, and intellectual deficiency. More common than these are temperament or attitude faults which are grave enough to impair a marriage and yet permit holding some kind of a job. These respond in some cases with the cooperation and guidance of the counselor to a point where the marriage can usefully continue. In others the "poor spouse material" is too resistant and the marriage fails in spite of the efforts of each kind of specialist who works with him. All in all, society would find it worth while to make a skillful attempt at reconstruction, when the diagnostic and prognostic study is favorable. Experience shows that where success is attained, it will usually be accomplished well within two months. It unduly jeopardizes the success of the whole venture to spend such a long time on the bad prognosis cases that are so expensive.

After the first state is won for the new non-adversary law, with a court staff for investigation and counseling, will it spread to other states? This depends largely on the kind of work the court staff will do. There are three approaches that should be evaluated.

In the first approach the attitude is that the purpose is to act as a brake to hold down the number of divorces. Where this is the purpose, obviously the numerous means for delay will be employed to the limit of the statute, regardless of damage to spouses. The method used is mainly limited to reconciliation. It is presumed, with little or no investigation of the particular case, that reconciliation is the wiser course. No attempt at comparative evaluation is made. In fact those addressed are sometimes several assembled couples. The material is largely a detailed and emotional picture of how, in certain cases, results were worse after a divorce, with the confident prediction that regret will be the main result if divorce is chosen. Such "counseling" continues throughout the six months and it will consist mainly of speeches by the staff member trying to persuade the spouse to say, "O.K. I will abandon the divorce idea and resume the marriage." Very little time would be spent on hearing the spouses tell their story, especially if it is critical of the other spouse or defensive of self, as that would not work toward the end already fixed in the investigator's mind. This method makes use of statistics giving the number of reported reconciliations in some such series. Such evidence is of very little value as results obtained in that way with no adequate follow-up have little validity. It might be called reconciliation by propaganda. Couples too often come back later or go to another state for their divorce.

A second approach emerges in which the main difference is that the spouses now do the talking. The counselor has very little to say. It is believed that the spouses 
will talk themselves into an insight if they talk for a long time and if the counselor will be content to be a listening post and a sounding board except for reflecting and clarifying. When the insight is attained the spouse "will know what to do." This method is relatively of low usefulness and unduly prolonged.

The third approach is characterized by a greater concern as to what the causative factors are and the way in which the counselor may use his knowledge in helping the spouses evaluate the situation and test out any chance of changing the undesirable conditions. Not only are the spouses encouraged to talk during the interviews but also they are asked to participate in studies of personality factors which may be judged by quantifiable tests and, through written answers, in an inquiry for thinking about the problems. The counselor thinks that diagnosis must be had if possible, both as to category and as to probable causative factors. He may find a personality factor or factors in one or both persons which need improvement or the environment may need some alteration. He directs his way of working toward improvement as a result of a knowledge of human behavior and ways of changing it and includes a sharing of plans of actions and an intellectual, sympathetic, and objective encouragement. Plans are altered as results indicate.

The length of time devoted to the process is largely determined by the nature of the difficulty and its amenability to the method of improvement employed. The techniques should be adapted to what the experience of the court staffs at Milwaukee, Toledo, and the Children's Court of Conciliation has shown is usually available as to time. Thus, in view of the limitations of time, the court staff does well to make considerable use of printed material with the spouses. Selected existing books and pamphlets and special material written for the purpose are needful. Staff members may be tempted for economy of time to see the spouses together. As a general practice this works badly. Only rarely for certain special purposes will it be useful. When done, it will sometimes be advisable to cut short the meeting and resume it only under rules of parliamentary limitation. If fair progress is made in reconstruction, the spouses will want to re-evaluate the pros and cons of divorce. This will mean to evaluate the probable results in the future for each child and for each spouse for each of the courses-divorce or no divorce. In this the counselor should respect the self determination of each spouse. However, with his larger fund of knowledge and experience he participates in keeping the evaluation as objective as may be and sees that as few significant factors are omitted as time permits. Where the prognosis and progress is found to be bad, the time available is transferred to cases with better prognosis and progress.

A main difference here is the recognition that some of these cases are very resistant to any of these three methods. How can the staff member hope to have great success with psychopathic deviates and paranoid personalities when these are known to be very resistant to counseling? As a consequence, there must be a sorting of the cases to report those with bad prognoses to the judge as soon as that is evident, in order to apply the full resources of the staff on those of more promise. The staff will 
therefore be able to handle a larger load and be permitted to close the case when termination is indicated rather than holding on to each for six months.

Marriage counseling of some sort has an unusual history in that it is attempted by so many persons of such varied interests and skills. The physician, psychiatrist, social worker, psychologist, and psychological sociologist all have some part of the needed training, but the efficient marriage counselor should be compounded of some of each of these disciplines plus specific material and techniques. The minister and priest have long been heavily utilized, less on their own initiative than by demand of the needy spouses. Their training was originally quite inadequate for this work but fortunately it is improving.

It must be admitted that at the present time facilities for properly training marriage-investigator-counselors are scarce and effort should be made toward improvement and extension of such education and training to meet the demand that is increasing. To make up a mixed staff from several specialties is a makeshift and cannot successfully meet the need of well rounded, broadly trained marriage-investigator-counselors. Yet specialists in more limited areas around such a nucleus can work well. Thus, the court staff will be more useful if it has an effective affliation with a medical and psychiatric clinic because weaknesses in the spouses in these areas are frequent and are often not receiving help.

It is obvious that the first and second approaches can be done with persons of meager training. However, the results we hope to get from the third court staff approach, are much more than can be had using only the first or second. The operation desired here calls for much and wide knowledge and skill, a fitting personality, and as much experience as may be had. Some colleges should start at once to train people for this work. Existing course sequences that could be built up most easily are Clinical Psychology, Social Work, and Guidance Counselors. Much, however, would need to be added to existing courses. It is important that special sequences pointing to the marriage-investigator-counselor work be organized and listed. Starts have been made at Pennsylvania State College, Florida State College, University of North Carolina, University of Southern California, Los Angeles State College, and the American Institute of Family Relations in Los Angeles, yet none of these has a regularly announced and listed course sequence.

In setting up qualifications for the staff positions it would be a mistake to stipulate at this time particular degrees in particular disciplines because experienced marriage counselors have come to their work from such various sources. Written examinations, practical tests, and oral interviews would have to be the main reliance in personnel selection.

The experience of the Children's Court of Conciliation in California makes it probable that we will have under the proposed new bill, counties with several levels of efficient operation of the staff: (a) excellent personnel in adequate amount; (b) excellent personnel but in inadequate amount; (c) inadequate quality of personnel; and (d) no budget is allowed for investigating-counseling staff at all. To meet 
this last difficulty, the suggestion has been made that there should be a traveling van service for the rural counties. There are serious objections to this method. First, there would be harmful delay in many cases. Second, the period in any one city is too short to accomplish the purposes with the efficiency desired. If the difficulty from either is reduced, the difficulty on the other horn of the dilemma increases. A better method to meet the difficulty is needed and is here proposed. Let the court, where it considers the staff to be inadequate or where it thinks some specialized service would be more useful than the staff can give a particular case, make reference of the case to some outside individual or agency. This is done both in the Children's Court of Conciliation and in the Swedish courts. A transferral of the case from court to outside agency or from agency back to court before the expiration of the time limit should be permitted for good reason. There is, of course, an obvious weakness here in that the outside individual or agency may be below the desired standard of efficiency and objectivity, but it would at least be generally better than the traveling van method or the absence of staff entirely in some counties.

Is it worth while trying to improve the lot of the unhappily married by counseling or divorce when really needed? There will be those who say no and argue: "Let us teach people not to expect romance; just accept marriage as a sort of partnership with little emotional expectation." This is thought of as a prophylaxis against divorce, which is held to result from wanting to get more happiness out of life than we have been getting. Instead of this, let us pursue earnestly the task of healthier, happier people. Let us not give up, but build up love and marriage and expect much from it, because we give much to it.

\section{APPENDIX}

It is urgent that the court staffs should function as well as possible from the first, especially in view of the scrutiny and prejudice that the pioneer staffs will meet. With this in view the remainder of this article will be of more technical interest to the workers in these staffs and therefore is added as an appendix.

In our experience at the American Institute of Family Relations we have found one of our great helps is a comprehensive temperament test furnishing a profile of the nine traits listed below which we know are significant of success or failure in marriage. Work on a revision is in progress, but no other trait that needs to replace the nine chosen has been found. One will be added, viz., response bias.

It is our practice to give the test routinely with a few exceptions. It is given at the end of the first hour. It is scored, profiled, and protocoled by clerical help and ready for use by the client and counselor for the second hour. The test should be taken on the first spouse by himself, also on the same person by the other spouse. The other spouse is asked to do the same. This constitutes what we call a "criss-cross." Where disparity is considerable, it is desirable to have it on each by third persons who are likely to know the client well and be as objective as may be.

The test we use is the Johnson Temperament Analysis, chosen because of its values given below. Other such tests, with enough suitable traits, which are available are the Guilford-Zimmerman Temperament Survey and the Adams-Lepley Personal Audit. They should be compared with the Johnson when values for marriage become available 
for them. This test is published by the California Test Bureau, 5916 Hollywood Boulevard, Hollywood 28, California. It should be scored with the weighted stencils, and the value norms to be used are those available in a supplement to the Manual available from the author.

Warning is given that the common use of percentiles or standard scores in any personality test as if they measured value in all traits is misleading. Value is obtained by a ratio of the frequency for any one raw score from a sample showing high value in features desired in percentage of all obtaining that particular raw score (ro). In this operation the number in the two samples is equal. In this system ro for any raw score would mean that only cases from the high value sample would be found, 5 that there were equal numbers, and o that only those from the less valuable sample were found. Three (3) would mean that $3 /$ Io were found to be from the more valuable sample.

Values for Marriage Success

\begin{tabular}{|c|c|c|c|c|c|c|c|c|c|c|}
\hline & & Nervous & $\begin{array}{c}\text { De- } \\
\text { pressed }\end{array}$ & Active & Cordial & $\begin{array}{c}\text { Sympa- } \\
\text { thetic }\end{array}$ & $\begin{array}{c}\text { Sub- } \\
\text { jective }\end{array}$ & $\begin{array}{l}\text { Aggres- } \\
\text { sive }\end{array}$ & Critical & $\begin{array}{c}\text { Self- } \\
\text { mastery }\end{array}$ \\
\hline \multirow{2}{*}{$\sum_{\Sigma}^{z}$} & $\begin{array}{l}6 \& \mathrm{Up} \\
\text { Excellent }\end{array}$ & $\begin{array}{l}*_{44}^{*} \& \\
\text { Down }\end{array}$ & $\begin{array}{l}50 \& \\
\text { Down }\end{array}$ & $\begin{array}{l}84 \& \\
U_{p}\end{array}$ & $\begin{array}{l}50 \& \\
U_{p}\end{array}$ & $\begin{array}{l}70 \& \\
U_{p}\end{array}$ & $30-50$ & 44 & $\begin{array}{l}24 \& \\
\text { Down }\end{array}$ & $\begin{array}{l}73 \& \\
\mathrm{U}_{\mathrm{p}}\end{array}$ \\
\hline & $\begin{array}{l}3 \text { \& Down } \\
\text { Bad }\end{array}$ & $\begin{array}{l}78 \& \\
U_{p}\end{array}$ & $\begin{array}{l}71 \& \\
U_{p}\end{array}$ & $1-$ & $\begin{array}{l}9 \& \\
\text { Down }\end{array}$ & $\begin{array}{l}2 \& \\
\text { Down } \\
\end{array}$ & $\begin{array}{l}96 \& \\
U_{p} \\
\end{array}$ & $\begin{array}{l}2 \& \\
\text { Down }\end{array}$ & $\begin{array}{l}95 \& \\
\mathrm{Up}_{\mathrm{p}} \\
\end{array}$ & $\begin{array}{l}7 \& \\
\text { Down } \\
\end{array}$ \\
\hline \multirow{2}{*}{ 窗 } & $\begin{array}{l}6 \& \text { Up } \\
\text { Excellent }\end{array}$ & $\begin{array}{l}39 \& \\
\text { Down }\end{array}$ & $\begin{array}{l}56 \& \\
\text { Down }\end{array}$ & $\begin{array}{l}83 \& \\
U_{p}\end{array}$ & $\begin{array}{l}42 \& \\
\mathrm{Up}_{\mathrm{p}}\end{array}$ & $\begin{array}{l}85 \& \\
U_{p}\end{array}$ & $6-42$ & $83-94$ & $\begin{array}{l}49 \& \\
\text { Down }\end{array}$ & $\begin{array}{l}85 \& \\
U_{p}\end{array}$ \\
\hline & $\begin{array}{l}3 \text { \& Down } \\
\text { Bad }\end{array}$ & $\begin{array}{l}85 \& \& \\
\text { Up }\end{array}$ & $\begin{array}{l}73 \& \\
\mathrm{U}_{\mathrm{p}}\end{array}$ & $\begin{array}{l}7 \& \\
\text { Down }\end{array}$ & $\begin{array}{l}26 \& \\
\text { Down }\end{array}$ & $\begin{array}{l}4 \& \\
\text { Down }\end{array}$ & $\begin{array}{l}99 \& \\
\text { Up }\end{array}$ & $\begin{array}{l}5 \& \\
\text { Down }\end{array}$ & $\begin{array}{l}93 \& \\
U_{p} \&\end{array}$ & 1. \\
\hline
\end{tabular}

- Scores are shown as percentiles.

These results correlate so well with various traits in the Minnesota Multiple Personality Inventory, although its norms are in term of psychopathic diagnoses, that the Johnson test acts as a good screener for the use of the Multiphasic test. If the value results in a Johnson Temperament Analysis are:

I or more traits with a value of $I$ or worse,

2 or more traits with a value of 2 or worse,

3 or more traits with a value of 3 or worse,

then the Multiphasic test should also be given. Giving due consideration also to the validity scores in this test one has a partial guide as to whether the case should receive the attention of the psychiatrist. These validity scores will also be taken into consideration in interpreting the Johnson scores when they are available.

A device which we find a useful supplement to a temperament test is one to help discover the causative factors. The temperament analysis is important because of its relatively high validity as compared with impressionistic diagnoses in the temperament field. But it does not help enough in the hunt for the causative factors. Here we have found the items in what we call the Johnson Attitude Inquiry helpful in forming hypotheses to be tested by oral questioning. In giving this inquiry the investigator marks the items to be discussed further orally with the client. It is not intended to be used alone but as a supplement. It will have limited value unless the hypotheses derived from it are adequately tested orally. It is well to have this inquiry done "crisscross" as with the Temperament Analysis. 


\section{Johnson AtTItude InQuir}

\section{Form $E$}

A Qualitative Supplement to Temperament Profiles of Self or of Other Person

It will help the counselor to understand the factors that have contributed to your present personality if you will please write something on each of the following topicsor on as many as you will. Write fully and give the name data as below and the date at the top of the sheet upon which you write.

Name of person about whom the information applies.

Name of person supplying the information is the same (underline if so) or

I. What has he or she done about which he or she is most pleased?

2. What does he or she consider his or her best qualities?

3. Has he or she had several intense interests, each of which took up much of his or her time and thought for a while? What, at what age, and what course did it take?

4. Did he or she ever have one or more experiences that affected him or her greatly? What, and how, and at what age?

5. How did he or she get on with others at school? And later, in his or her work? If there was difficulty, why?

6. What is the worst blunder, or blunders, he or she has made? What brought it about?

7. Does he or she have inferiority feelings? About what? How did they come about?

8. During what year of his or her life did the most rapid and important changes in his or her personality take place? In what ways and why?

9. Is he or she worried about anything? What, and why?

I0. What are the outstanding traits of any of his or her relatives, naming the relationships.

xx. How have his or her personal relationships to any person been an influence in shaping his or her personality?

12. What individuals in history or current affairs, or book or article, have had the most influence on him or her? In what way?

13. What individuals in public life or private life, past or present, does he or she especially admire or dislike, or wish to be like? Why?

14. If he or she is not married, why? If he or she is married, how does, or did, marriage affect him or her?

15. Under what conditions is he or she most happy? Why?

I6. Under what conditions is he or she most unhappy? Why?

17. What is his or her philosophy of life now? Any change in recent years?

18. What does he or she consider the most important two or more reforms in order of importance?

rg. With the views or actions of what groups of people does he or she feel the strongest agreement and with what the strongest disagreement? Why?

20. In a long conversation, what topic or topics is he or she likely to introduce?

2I. What is the fault in others about which annoyance is most frequently expressed?

22. Describe the qualities of a person whom he or she would most like to be.

23. Is there any person or group who is consciously working against him or her in his or her opinion? Who and why?

24. Suppose he or she had much leisure time because of a month's convalescence, what would he or she like to do with it?

25. If he or she were an artist and were to paint a picture for self-satisfaction, describe it. 
26. If he or she were hired to write a story, what plot (briefly stated) would he or she most likely use?

27. If he or she inherited ten million dollars tomorrow, what would he or she do because of it?

28. Has his or her religion or politics undergone a marked change at any time? When and why?

29. Imagine that in a dream a good fairy tells him or her that he or she may have three wishes. What would he or she choose? Why?

30. Suppose he or she had the privilege of an hour's conversation with some noteworthy personage dead, alive, or fictional, whom would he or she choose? What would he or she ask, or want to know about?

3I. What is there about himself or herself that gives him or her the greatest concern? Why?

32. What is there about some person (a husband, wife, child, parent, a friend or acacquaintance) that gives him or her the greatest concern? Why? Which of the relationships does that person bear to him or her?

33. Does he or she have "ups and downs"? How would you describe them? Do they seem to have a rough regularity as to intervals? Or is it brought on by any special kind of situation? If so, what kind?

34. Does he or she have conflicts of moment with any other person or persons? What about? With whom most often? What results? What relationship to him or her does that person or persons have?

35. Give a brief history of his or her health. What it its present condition?

Finish the following sentences and continue the discussion:

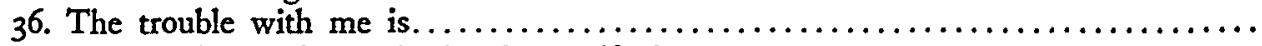



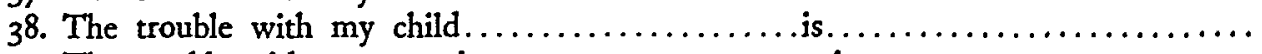

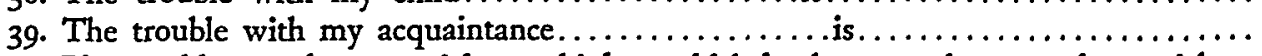

40. Please add any other material you think would help the counselor to understand how he or she has come to have his or her present personality.

A preliminary manual is available. This Inquiry is not copyrighted as it is desirable to revise it further from additional experience. It has been through four revisions so far. It is available for copying by anyone or copies can be had from the American Institute of Family Relations.

Mention is made of counseling sheets directed to the improvement of traits, difficulties, or situations. Sheets are available from the American Institute of Family Relations, ${ }_{5827}$ Sunset Boulevard, Los Angeles 27, California, for the nine traits in the Temperament Analysis and other topics listed in a leaflet. Others are added from time to time, sometimes appearing when issued in the periodical Family Life. As an illustration there is this additional sheet supplemental to the regular one on Improving Criticalness.

\section{Justifiable Criticism}

I. The criticism should be sound, i.e., if followed up, it would produce worth while improvement.

2. It should not concern something which is merely a matter of taste.

3. It should be so clearly stated as to be understood as meant.

4. It should have a good chance of being acted upon. If it is sure to be rejected, it should not be made. 
5. It should not produce more harm than good. This harm might arise from:

A. Badly hurt feelings of the criticized one.

B. A resentment so grave that enough hostility to the critic is produced as to seriously impair rapport.

C. It should not produce such strong inferiority feelings as to discourage efforts toward improvement.

6. It should not be something too trivial to risk making a criticism.

7. Not given at an inopportune time.

8. Not given in the presence of others (with a few exceptions).

9. Not given at so great a length or over-repeated to the point that the person criticized loses the benefit of an earlier gain.

I0. The manner and voice should avoid impatience, anger, sarcasm, contempt, shrillness, or sharpness, but be kept persuasive and friendly, realizing that one's traits are not for the most part deliberately and freely chosen.

II. The choice of words is of the utmost importance. The words must not be those, if possible, in which the basic meaning carries with it offensive side effects.

Finally, the writer would plead for more marriage counseling directed not solely at the unconscious or emotional, all very well in their place, but also to attitudes on an intellectual basis. We do not make enough use of philosophy of life, especially with the depressed; this applies particularly to the cultivation of objectivity and greater emphasis on the ethics of the results of the act, rather than on authoritative codes, or the social opinion of one particular group in one place at one time.

To be more specific there is given here the outline which the writer would be most likely to have in mind in a marriage counseling case, recognizing the need for individual adaptation and limitations of the time available.

\section{Outline of General Procedure in Marriage Counseling}

First Session.

I. Start with, "What do you think needs to be changed? Or, if you prefer, you may start with something else." If client is much ill at ease, proceed with some rapport-making conversation. Client then talks freely following his own order. The counselor makes at least mental note of some obscurities or blocking or omissions to be cleared up later. In order to maintain rapport, the counselor does not go to the Rogers extreme of " $U \mathrm{~m}$ Um" and mere reflection and clarification, as this sometimes embarrasses the client and rapport is damaged. Some comment is given as a lubricant if needful, such as "Yes, I understand that well," or "I have had a similar experience," or "Yes, I know the feeling," or "That pleased you, I can see," or "Yes, that is a common experience."

II. Last Io minutes of first session.

A. Symptomatic therapy started on some one item which seems safe even from this limited data, usually some active therapy.

B. Giving out the test program (temperament analysis and attitude inquiry).

C. Some appropriate reading suggested.

Second Session.

I. A. "What has occurred to you since your last visit that you think you would like to add to your account which you gave last time?"

B. "What have been the developments since?"

C. Ask questions to fill in important gaps that have been left.

D. Where it would be helpful, ask for a written account of a quarrel or some other feature. 
E. By this time the profile, reports, oral statements and answers will have permitted development of some hypotheses of category and origin. Ordinarily the hypotheses will be in the following list:

I. Situational-roughly to to 20 per cent.

a. Inadequate housing.

b. Inadequate medical care.

c. Inadequate food or poor food habits.

d. Inadequate clothing.

e. Narrow life because of inadequate expenditures for "higher life."

f. Housing with others $\left\{\begin{array}{l}\text { diffcult in-laws } \\ \text { difficult relatives } \\ \text { difficult roomers. }\end{array}\right.$

g. Neighborhood with persons of bad influence on $\left\{\begin{array}{l}\text { children } \\ \text { spouses. }\end{array}\right.$

h. Inter-spouse conflict.
(I) Differing in religion as it affects
sex attitude
birth control
number of children
ethical method
diet and calendar.

(2) Differing seriously in interests.

(3) Differing as to socially imposed patterns of action.

2. Personal一roughly 80 to 90 per cent.

a. Bodily defects contributing to inferiority feeling or temperament faults.

b. Capacity to earn living.

c. Infertility.

d. Adequacy as a companion.

e. Amative adequacy.

f. Sexual adequacy.

g. A marked difference in attitudes such as

(I) Rigidity in one spouse, fluidity in other,

(2) Conservatism in one spouse, novelty in other.

(3) Conformity vs. Independence.

h. Similar faulty attitudes in both where extreme.

i. Interests are weak or the difference in them is great.

j. Complexes that are disturbing to self or spouse.

k. Temperament (all the temperament traits have significance for marriage success although some in only part of their range; most notable are nine chosen for the Johnson Temperament Analysis together with rigidity; they may be single or in syndromes, neuroses or psychoses).

1. Level of intelligence or difference in intelligence which is effective largely in adequacy of interests, attitudes, efficiency, etc.

F. Test the hypotheses for their soundness by questioning for the consequences to be expected, if the hypothesis is correct.

Later Sessions.

Free opening as in second session.

Events and progress. 
Proceed with therapy after achieving insights by planning with client a campaign.

Appropriate therapies are initiated, usually several (see Thorne* list and a supplemental list attainable from the American Institute of Family Relations).

In general the outline is as follows:

I have this trait.

In this degree it is too high or low.

I know what to do to change it.

I will do it.

He can carry out the program.

$\mathrm{He}$ is so constituted that such a program will work with him.

- Frederick C. Thorne, Principles of Personazity Counseling (I950). 